\title{
The Influence of the Weather and Climatic Conditions and some Hydrological and Chemical Characteristics of the Someș River, in the NW part of Romania
}

\author{
Adriana Muntean ${ }^{\mathrm{A}}$, Irina Smical ${ }^{\mathrm{B}}$, Eugen Nour ${ }^{\mathrm{C}}$ \\ Received: September 14, 2014 | Revised: January 21, 2015 | Accepted: February 28, 2015
}

\begin{abstract}
This study highlights the influence of the quantity on the rainfall and air temperature recorded at the hydrographic station Ulmeni (in the Maramures County, in the N-W part of Romania), on the Someș River flow rate and some general physico-chemical parameters $\mathrm{(pH}$, total disolved solids and suspended matter).

Someș River is a left tributary of the Tisa River on the Hungarian territory, and is part of the SomeșCrasna hydrographic catchment, summing $5528 \mathrm{~km}$ network length coded, who drains an area of $15740 \mathrm{~km}^{2}$.

Interpretation of the collected data and statistical processing has demonstrated that the fluctuations of the flow rate of the river are closely dependent on the seasons from the considered period (2004-2012) and correlations between hydrological and chemical parameters. Because a large part of the Someș River crosses the human settlements and important agricultural areas, the study may be useful in the prediction of flooding and drought risks.
\end{abstract}

Key words: Someș, flow, hydrographic basin, physico-chemical parameters, risk, Romania.

\section{Introduction}

One of the greatest threats facing the world today is the global climate change. The working group experts of the Intergovernmental Panel on Climate Change (IPCC), in „The Physical Science Basis Working Group I Contribution to the Fifth Assessment Report of the Intergovernmental Panel on Climate Change" (Thomas, et al., 2013) unanimously agree that the warming of the global climate is a reality. The same group of experts argues that the period 1995-2006 is the period of 11 years with the highest recorded instrumental heat on the globe.
Besides, it is unanimously accepted the fact that there is an increase of the periods with high temperature, identically with short period of rainfalls, characterized by intensity and high quantities of water, with imminent risks of floodings in different sectors of the rivers and special socio-economical implications (Nacu, Muntean, 2010).

Ben Aissia, et al. (2011) argues that when simulating a hydrological event, two approaches are being tackled, which concentrate on a multivariate analysis of some variables like: the peak of the high flood,

\footnotetext{
A Maramureș Water Management System, Someș-Tisa Basinal Water Administration, 2 Aleea Hortensiei, Baia Mare City, Maramureș County, Romania, adriana1567_muntean@yahoo.com

B Faculty of Mineral Resources and Environment, Technical University of Cluj-Napoca, North University Centre of Baia Mare, 62A Victor Babeş Street, Baia Mare City, Maramureş County, România, irina.smical@yahoo.com

c Environmental Sciences Department, Babeş-Bolyai University of Cluj-Napoca, 30 Fântânele Sreet, Cluj-Napoca City, Cluj County, România, eugen.nour@yahoo.com
} 
the volume and the duration of the rainfall. The study concludes that, no matter the model chosen at the simulation, it is necessary to take into account the short period variations of the variables for recalibration of the model in due time, based on the correct description of the correlations between its history and future.

As a result, for future studies of modeling, we have chosen to evaluate the dynamic of some climate variables: the temperature of the air and of the rainfall, and the variations of the flow of the main river which passes the interest area (river Someș, on the right part of Ulmeni city, Maramureș County, Romania) and its influence on the $\mathrm{pH}$ reaction, on the matter concentration in suspension and in the fix residue.

The statistic processing of the meteorological data (the air temperature and the rainfall volume), hydrological (the river flow), collected by the hydrological station Someș at Ulmeni and of some physico-chemical parameters of water quality from Someș river $(\mathrm{pH}$, total disolved solids and suspended matter), in the same section, have permitted their interpretation and establishing some conclusions related to the climate risks from the excess or deficiency pluviometric periods, in an area with great agricultural potential.

\section{The characteristics of the reasearch area}

An important hydrographic Romanian basin, SomeșCrasna is represented by the basins of the rivers Someș and Crasna, which are independently collected by the river Tisa, the left affluent of the Danube. The hydrographic basin of Tisa river in the Romanian sector, is situated in the North part of Romania (E-W orientation) and it is delimited by the Maramureș Mountains, Oaș Mountains, the Maramureș Depression and the Carpathians Mountains (Ukraine). The main left tributary of Tisa - the Tur river, collects the rivers of the Someș hydrographic basin, and marks the border with Hungary on a length of $1.1 \mathrm{~km}$ (ACW, 1992).
The Someș hydrographic basin has $5528 \mathrm{~km}$ length of encoded network and it drains an area of $15740 \mathrm{~km}^{2}$. The middle course of Someș passes through the Baia Mare Depression, and the inferior one passes through the Someșului Filed and a part of Hungary (Badea, et al, 1992).

The interest area (Figure 1) is represented by Ulmeni city, where Somes River flows by, and on the bank of Somes River a hydrometric and pluviometric station is located. Ulmeni city is situated on the South-West part of Maramureș County, in the Baia Mare Depression, on the bottom of Chioar and Sălaj Hills. The characteristic relief of the Baia Mare Depression, with hights which pass over $1700 \mathrm{~m}$ and the Benesat-Țicău Defile created by the Someș River in this area, gives a climate with a moderate continental character (Badea, et al., 1992, S-T WB 2013, EPAMM, 2014). From the total area of Ulmeni city, the biggest area is the agricultural one (43.3\%), followed by the area with the arable field $(27.2 \%)$.

The implementation of the Directive 2007/60/CE (related to the evaluation and the risk management of the floods, has as its aim the decrease of the negative consequences for the human health, the environment, the cultural heritage and the economic activity associated to floodings), transposed through HG 846/2010 the approval of "The National Strategy of Risk Management of Floodings on a Medium and Long Term" has materialized through the creation of the maps for the hazard and risk of floodings in March 2014.

The Someș River in the Ulmeni section represents an important knot of spreading in the Maramureș County, of the wave of high flood in the case of floodings, like it is emphasized in the map (Figure 2), with the areas having a highly potential risk of floodings, the flooding areas and the risks associated to floodings of Someș River in the section of Ulmeni city, a case with medium probability, meaning for maximum flows with a probability of exceeding $1 \%$, floodings which can appear once in 100 years, published in
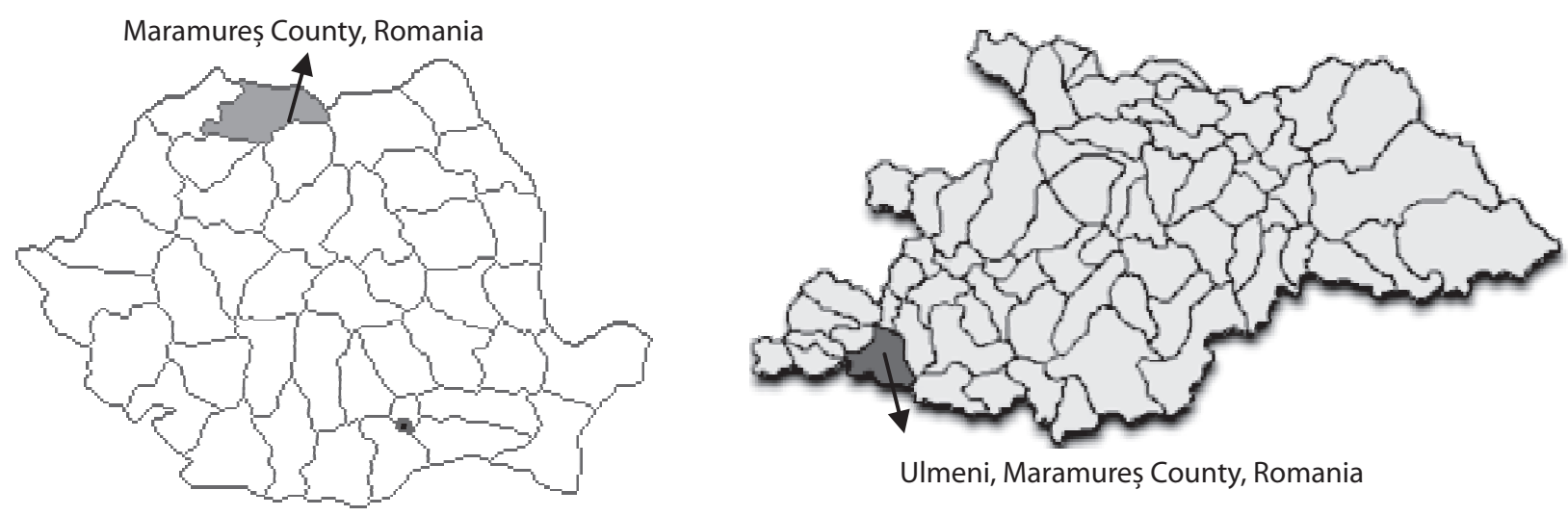

Figure 1. The areas of interest - Ulmeni City, judetul Maramureș County, Romania 


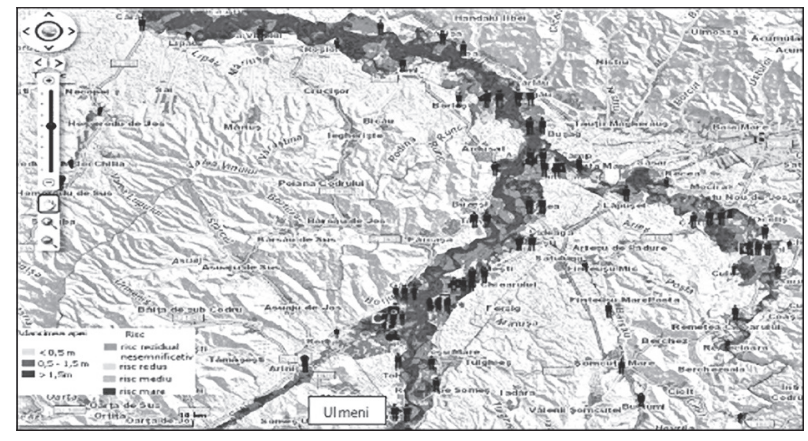

Figure 2. Risk and hazard map, the flooding areas and risks associated to flooding, of the Someș River in the section Ulmeni

Source: RWNA, 2014

2014, by The "Romanian Waters" National Administration, at scale 1:25000 (RWNA, 2014).

\section{Method and data}

Placing the climate of an area in a certain typology is made with the help of many climatic indicators (Courtillot, et al., 2013), the rainfall and the atmospheric temperature being the main factors in calculating these indicators.

The intensity, the duration and the frequency of the rainfall, associated with sudden variations of air temperature, are some of the characteristics directly or indirectly implicated in the extreme climate phenomenon - drought, high flood, floodings, with significant socio-economical impact (Ben Aissia, et al., 2014, Chebana, et al., 2011, Bronstert, 2003).

For characterizing the temporal variability of floodings and of monthly temperatures, in compari- son with the monthly average termo-pluviometric regime, registered in the period 2004-2012 at the hydrometric station Ulmeni, on the Someș River, we have used statistic modeling, the standard deviation type, to which we have applied the Bessel correction (which equals to $\sqrt{n / n-1})$, type $\mathrm{n}$ ). The statistic calculation was made with the aid of Excel, from Microsoft Office, using the STDEVP function.

Figure 3 shows an important variability of the rainfall in the analysed period; the rainfalls were almost missing in August, September and November, but they could touch maximum values in July, up to 227.5 $\mathrm{mm}$. The period of May-August, analysed with the aid of the standard deviation type, presents the biggest variation amplitude of rainfalls registered in the period 2004-2012.

The temporal variability (2004-2012) of the monthly air temperatures in comparison with the monthly average regime at the hydrometric station Ulmeni, on the Someș River is shown in Figure 4. It can be seen that the months February, September and October present the biggest variation amplitude of average monthly temperatures registered in the period 20042012.

The calculation of the variation coefficient of monthly rainfalls and of the average monthly temperatures shown in Table 1, allowed the quantitative interpretation of the rainfalls variabilitations, versus the average monthly air temperatures.

It can be estimated that for August, in the analysed period (2004-2012), the monthly rainfalls had the biggest temporal variability of $\mathbf{1 2 . 7 2}$ times bigger in comparison with the average monthly temperatures.

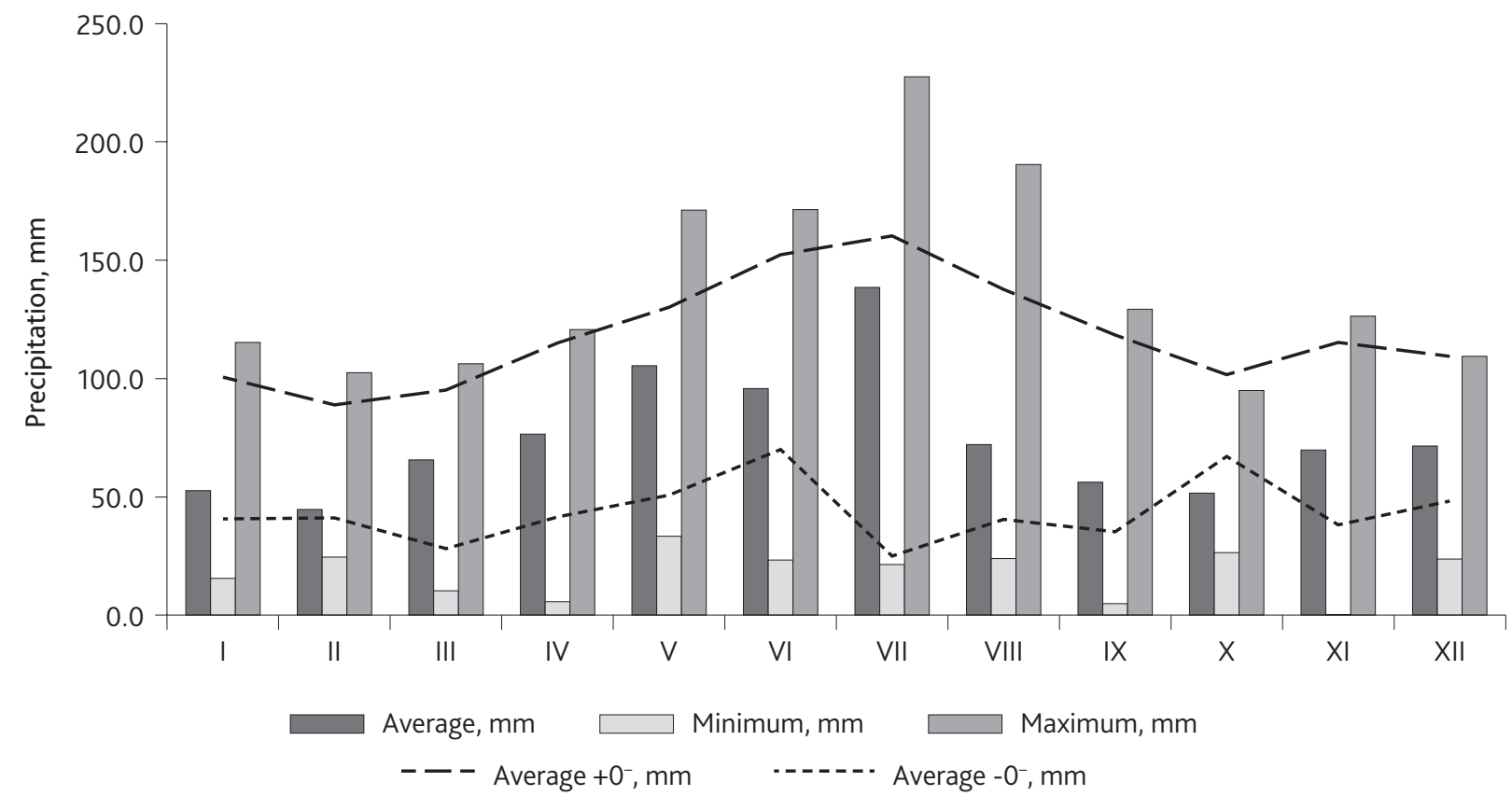

Figure 3. The variability of precipitation recorded at the hydrometric station Ulmeni, in the period 2004-2012 


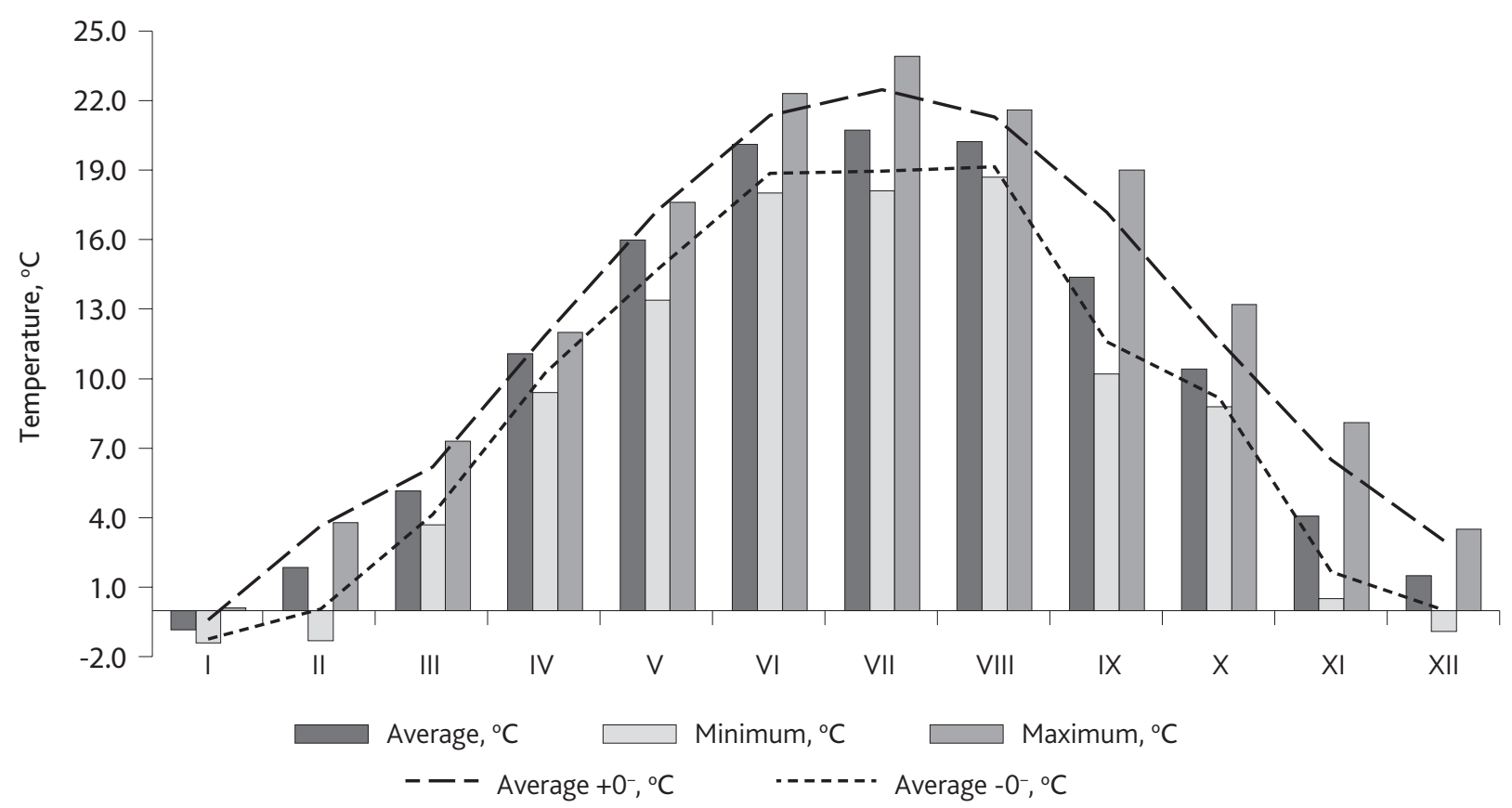

Figure 4. Variability of air temperature recorded at the hydrometric station Ulmeni, during of period 2004-2012

Table 1. Coefficients of variation of the precipitation and a monthly average temperatures, in the period 2004-2012 Climatic indicator The monthly variation coefficient, \%

\begin{tabular}{|c|c|c|c|c|c|c|c|c|c|c|c|c|}
\hline \multirow{2}{*}{ Climatic indicator } & \multicolumn{12}{|c|}{ The monthly variation coefficient, $\%$} \\
\hline & I & II & III & IV & v & VI & VII & VIII & IX & $x$ & $\mathrm{XI}$ & XII \\
\hline Precipitation & 56.7 & 53.6 & 51.2 & 47.9 & 37.7 & 43.0 & 48.8 & 67.4 & 74.0 & 33.6 & 55.3 & 42.7 \\
\hline Air temperature & 49.6 & 96.1 & 19.7 & 7.4 & 8.0 & 6.3 & 8.5 & 5.3 & 19.4 & 11.9 & 59.3 & 99.0 \\
\hline
\end{tabular}

For the analysed period we calculated the Standardised Precipitation Index (SPI), developed by the researchers McKee, Doesken and Kleist from Colorado State University, at the beginning of 1990, for the identification and characterisation of drought periods (Arba, 2012, McKee et al., 1993). Applicable for any relief form, according to the obligations of the World Meteorological Organisation (OMM) and of the National Drought Mitigation Center (NDMC, Internet 1), the interpretation of the algebric values obtained is made according to the steps emphasized in Table 2 - to which the types of climatic risk are attached.

Table 2. Excessive or deficitary periods in precipitation and type of the risk

\begin{tabular}{|l|l|l|}
\hline Value of SPI & Qualification & Type of risk \\
\hline$>=2$ & extremely wet & high risk \\
\hline $1.5-1.99$ & very wet & average risk \\
\hline $1.00-1.49$ & moderately wet & low risk \\
\hline$-0.99-0.99$ & almost normal & no risk \\
\hline$-1.0 \ldots-1.49$ & moderately droughty & low risk \\
\hline$-1.50 \ldots-1.99$ & very droughty & average risk \\
\hline$<=-2$ & extremely droughty & high risk \\
\hline
\end{tabular}

For the analysis of the pluviometric deviation, registered in the period 2004-2012, at the hydrometric station Ulmeni, on the Someș River, the SPI values between $(-1.49 \div 1.49)$ were not considered. Thus, 2007 was the only year almost normal (moderately wet or droughty) from the period 2004-2012. In Table 3 the calculated values of SPI are shown, for each year and month outside the interval $(-1.50 \div 1.50)$.

The year 2012 is the only one from the analysed period with 2 months extremely droughty (March and July) and one, very droughty (September).

The calculation of the aridity value De Martonne $\left(\mathrm{I}_{\mathrm{M}}\right)$, like a ratio of annual rainfalls to average annual temperature, at denominator additionally stepping in a value of $10^{\circ} \mathrm{C}$, for producing positive results for the regions with negative annual termic average too, for the period 2004-2012, allowed the delimitation of the years with wet, moderately wet, moderately arid and arid climate (Figure 5).

The graphic representation from figure 5 , shows the tendency of the climate from the area of becoming moderately wet in the last 2 years of the analysed period (2011, 2012).

Many studies (Khaliq, et al., 2009, Kao, Govindaraju, 2007, Bronstert, 2003, Goel et al, 2000, Best, 
Table 3. Excedentary or deficitary periods in precipitation and type of the risk, in period 2004-2012

\begin{tabular}{|c|c|c|c|c|}
\hline \multirow{2}{*}{ Year } & Month & SPA value & Qualification & Type of risk \\
\hline \multirow{2}{*}{2004} & VII & 2.06 & extremely wet & high risk \\
\cline { 2 - 5 } & VIII & 1.68 & very wet & average risk \\
\hline \multirow{2}{*}{2005} & VII & 2.92 & extremely wet & high risk \\
\hline \multirow{2}{*}{2008} & VIII & 2.29 & extremely wet & high risk \\
\hline \multirow{2}{*}{2009} & VII & 2.79 & extremely wet & average risk \\
\hline \multirow{2}{*}{2010} & IV & -1.51 & very droughty & average risk \\
\hline \multirow{2}{*}{2011} & IX & -1.52 & very droughty & average risk \\
\hline \multirow{2}{*}{2012} & VII & 1.89 & very wet & high risk \\
\hline & VII & 2.48 & extremely wet & high risk \\
\hline & XI & 2.03 & extremely wet & average risk \\
\hline & III & -1.98 & very droughty & high risk \\
\hline
\end{tabular}

Roberts, 1975), have shown through different statistical quantifications (correlations Pearson, test Sperman, Kendall's Tau), the dependency of the surface overflows in corelation with the intensity and duration of the rainfalls in hydro-meteorological and geomorphological prediction.

Irrespective of the correlations and the model used in the prediction of the geomorphological changes of a river, it is obvious the fact that besides geomorphological changes that may occur into the riverbed, the water quality is of course, influenced (Pantelić, 2013, Reynard, et al., 2001).

In strict accordance with the emphasized tendency of the climate from the area, the values of the flow of Someș river monitorized at the hydrometric station Ulmeni, decrease from 2009. From the analysed period, in 2012 the smallest values of the flow of Someș river in this section were registered, as presented in Figure 6.

The extremely small flows registered at the hydrometric station Ulmeni for Someș river, in the last 2

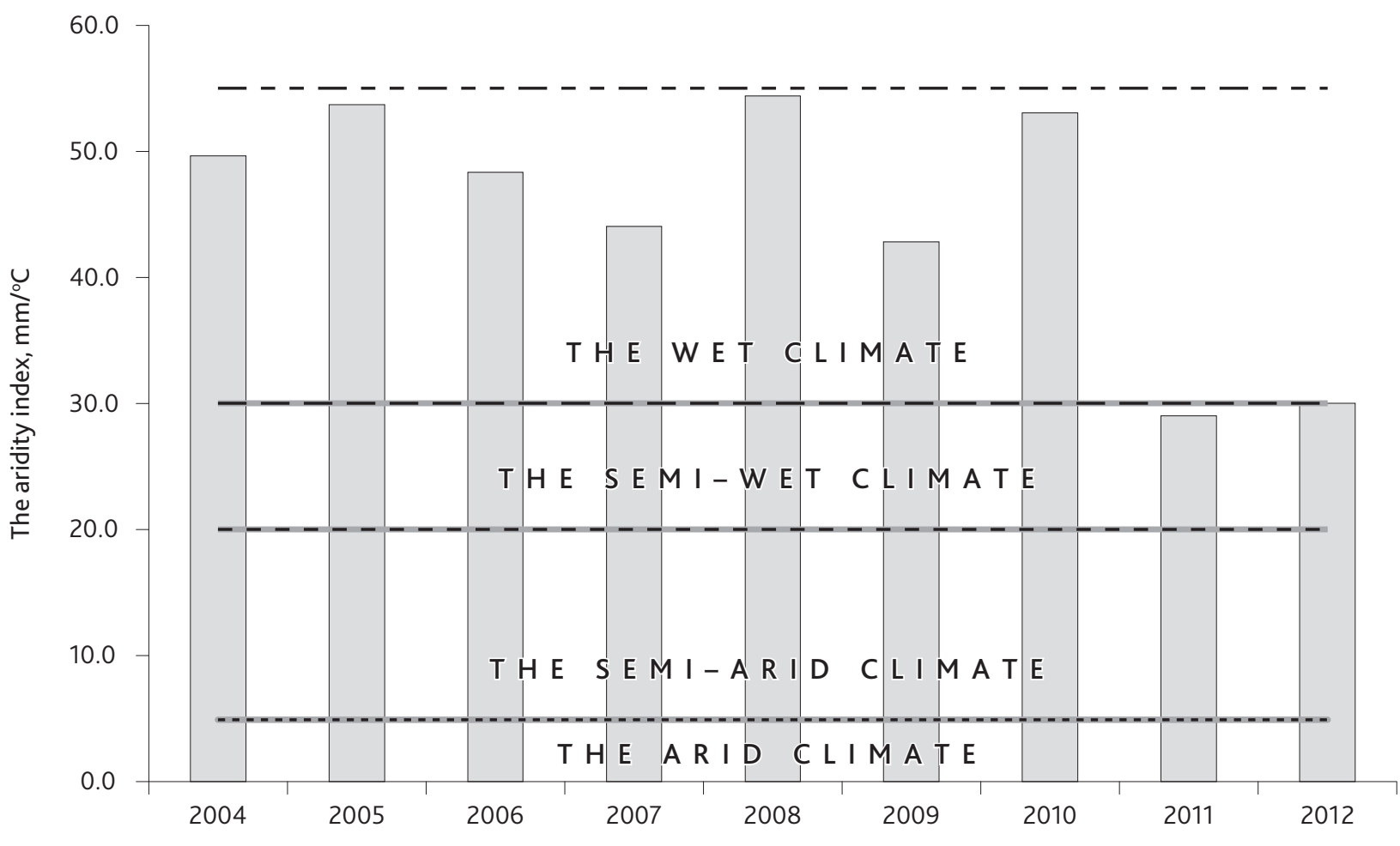




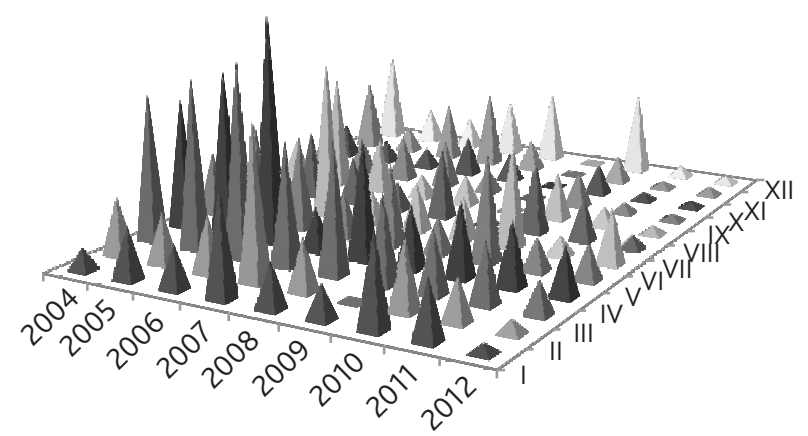

Figure 6. Dynamics of the flow Somes River at Ulmeni hydrometric station in period 2004-2012

years from the analysed period, together with the calculated pluviometric quantifier, confirm the value of aridity of the area and the instalation of the moderately wet climate.
It is known the fact that the extreme phenomenon of the climate which implies droughty periods, alternatively with short periods with important rainfalls, short and very intense, are responsible for the breaking of the river bed, moving the deposites from the water of the river. It is possible that in a short period of time, the quality of water is modified, with important implications on that ecosystem. The concentration of the suspended matter, of total dissolved solids and the reaction of the water $\mathrm{pH}$ are 3 of the immediate indicators which give information about moving the solid matters and/or alluvium in the case of some climate phenomenon.

In Figure 7 we have emphasized the $\mathrm{pH}$ dinamycs of the Someș River at Ulmeni hydrometric station in the period 2004-2012. It can be concluded that the average value of the $\mathrm{pH}$ it is situated between 7.65-7.92, being in

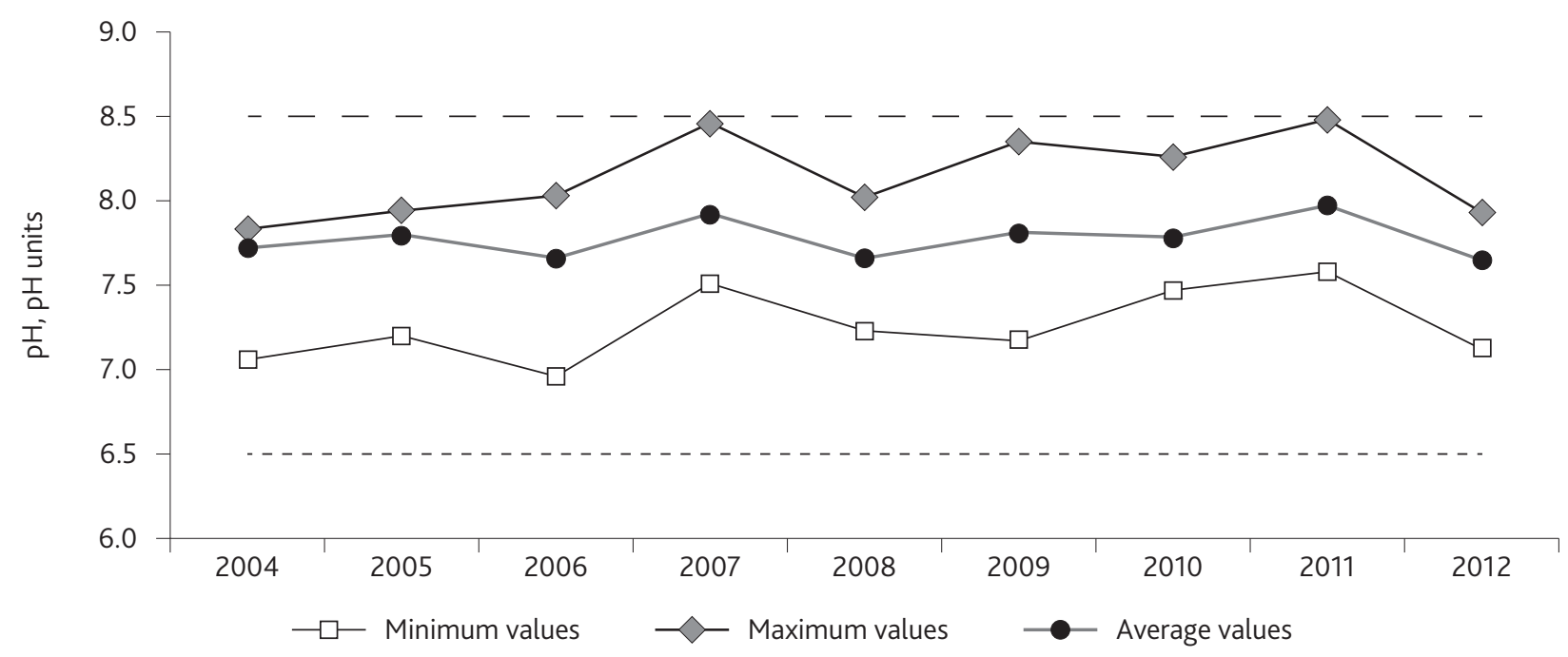

- - - Minimum admisible value by Order 161:2006 _ _ - Maximum admisible value by Order 161:2006

Figure 7. The $\mathrm{pH}$ dynamics of the Someș River at hydrometric station Ulmeni in period 2004-2012

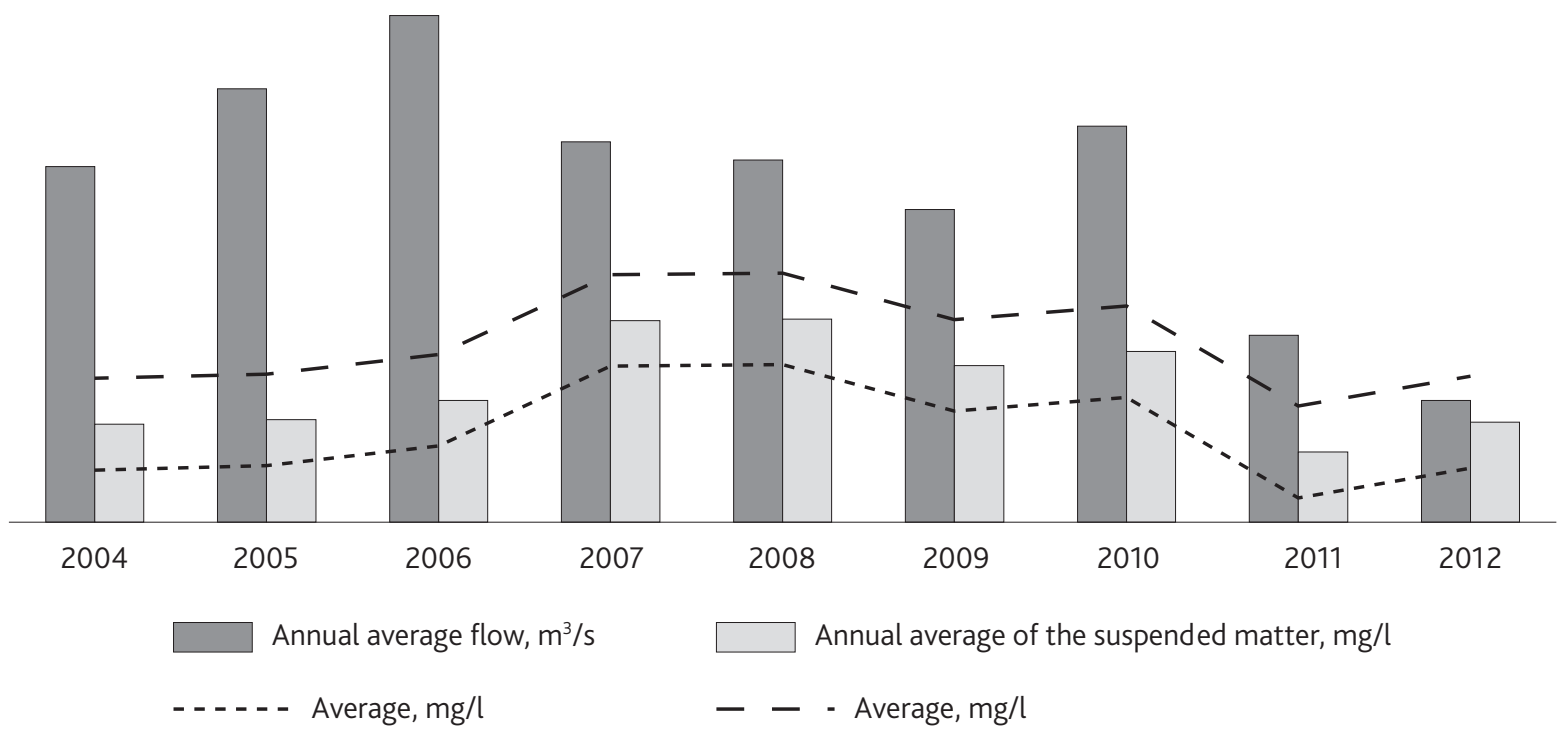

Figure 8. Evolution of the suspended matter of the Someș River at hydrometric station Ulmeni in period 2004-2012 


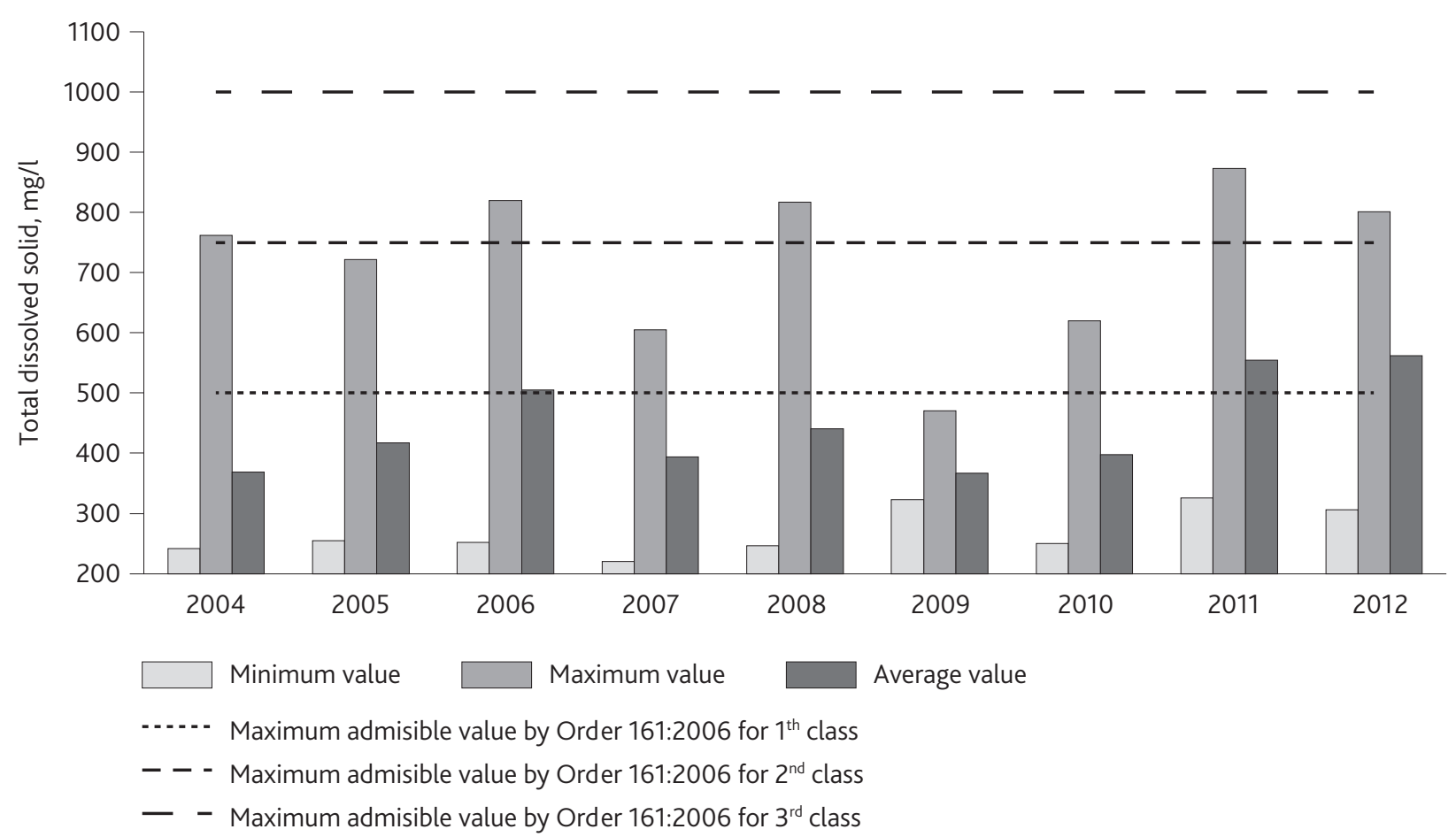

Figure 9. Dynamics of the total dissolved solid of the Someș River at hydrometric station Ulmeni in period 2004-2012

this way in the interval admited by the Romanian regulations in effect - Order no. 161:2006 - Normative of the classification of surface water quality to determine tha ecological status of water bodies, in Romania.

Along with the decrease of the water flow from the river bed, the evolution of the concentration of the suspended matter is situated in the standard average deviation calculated as shown in Figure 8.

The dynamics of the total dissolved solid (TDS) of the Someș River at Ulmeni hydrometric station is revealed in Figure 9. It is noticed that the biggest value was registered in 2011, placing the quality of water in IIIrd class, for this indicator, the same as in 2004, 2006, 2008 and 2012. On the other hand, the biggest average values of TDS, which determine the placing in the Ist class, were determined only for the years 2011 and 2012. The high concentrations determined for this indicator can be explained due to the decrease of the flow of the river, together with the small quantities of rainfalls registered in these periods.

\section{Conclusion}

The statistic and graphic analysis of the data collected in the period 2004-2012 at the hydrometric station Ulmeni for Somes, river, have shown the fact that the average monthly air temperatures present the biggest variations amplitudes in February, September and October.

The calculation of the SPA value has permitted the emphasis of the pluviometric abnormalities, the year
2007 being the only one, from the analysed period, without wet or droughty extremes.

Starting from the year 2011, according to the aridity value De Martonne (IM), the climate from the area becomes from the wet one in semi-wet.

In the year 2012 the smallest values of the flow of Someș river were registered, in strict accordance with the tendency of the climate from the area and the concentrations of the quality indicators $\mathrm{pH}$, suspended matter and TDS, which are in strict accordance with the decrease of the flow of the river and with the small quantities of rainfalls registered in the analysed period.

The study highlights the climate change of the study area and can be a starting point in many other areas: agriculture, tourism and agro-tourism, environment, etc., and may serve the institutions involved in managing situations generated by floods.

\section{References}

Arba, A.M. 2012. The Period of Pluviometric Surplus from the Timiș Hydrographical Basin (1965-2009). Forum geographic. Study and research of Geography and Environment XI-2, 209-213, http://dx.doi. org.10.5775/fg.2067-4635.2012.080.d

Badea, L., Bugă, D. 1992. Geografia României. Regiunile pericarpatice, Dealurile și Câmpia Banatului și Crișanei, Podișul Mehedinți, Subcarpații, Piemontul Getic, Podișul Moldovei, vol. IV, Romanian Academy Press, Bucharest, 580 pp. (in Romanian). 
Ben Aissia, M.A., Chebana, F., Ouarda, T.B.M.J., Roy, L., Bruneau, P., Barbet, M. 2014. Dependence evolution of hydrological characteristics, applied to floods in a climate change context in Quebec, Journal of Hydrology 519, 148-163.

Ben Aissia, M.A., Chebana, F., Ouarda, T.B.M.J., Roy, L., Desrochers, G., Chartier, I., Robichaud, É. 2011. Multivariate analysis of flood characteristics in a climate change context of the watershed of the Baskatong reservoir, Province of Québec, Canada. Hydrological Processes 26-1, 130-142.

Best, D.J., Roberts, D.E. 1975. Algorithm AS 89: the upper tail probabilities of Spearman's rho. Journal of Applied Statistics 24, 377-379.

Bronstert, A. 2003. Floods and climate change: interactions and impacts. Risk Analysis 23-3, 545-557.

Chebana, F., Ouarda, T.B.M.J. 2011. Multivariate quantiles in hydrological frequency analysis. Environmetrics 22-1, 63-78.

Courtillot, V., Le Mouël, J.L., Kossobokov, V., Gibert, D., Lopes, F. 2013. Multi-decadal trends of global surface temperature: A broken line with alternating 3oyr linear segments? Atmospheric and Climate Sciences 3, 364-371. http://dx.doi.org/10.4236/ acs.2013.33038

Directive 2007/60/CE on the assessment and management of flood risks, Official Journal of the European Union L 288, 27-34.

Environmental Protection Agency of Maramures County (EPAMM), 2014. Report on the state of the environment in Maramureș County.

Goel, N.K., Kurothe, R.S., Mathur, B.S., Vogel, R.M. 200o. A derived flood frequency distribution for correlated rainfall intensity and duration. Journal of Hydrology 228-1,2, 56-67.

Kao, S.C., Govindaraju, R.S. 2007. Probabilistic structure of storm surface runoff considering the dependence between average intensity and storm duration of rainfall events. Water Resources Research 43-6, Wo6410 15pp.

Khaliq, M.N., Ouarda, T.B.M.J., Gachon, P., Sushama, L., St-Hilaire, A. 2009. Identification of hydrological trends in the presence of serial and cross correlations: a review of selected methods and their application to annual flow regimes of Canadian rivers. Journal of Hydrology, 368 (1-4), 117-130.

McKee, T.B., Doesken, N.J., Kleist J. 1993.The relationship of drought frequency and duration to time scales. Preprints, $8^{\text {th }}$ Conference on Applied Climatology, pp. 179-184, Anaheim, California.
Minister Order no. 161 of 16 February 2006 the Minister of Environment and Water for approving the Norms concerning the classification of surface water quality to determine the ecological status of water bodies, published in M.Of. no. 511/13 ${ }^{\text {th }}$ Jun. 2006 (in Romanian).

Ministry of Environment, (1992), Cadastre Atlas of Water from Romania - Part 1 Morpho-hydrographic Data on the Hydrographical Network, Aquaproiect S.A., Bucharest, pp. 695 (in Romanian)

Nacu, S., Muntean, A. 2010. The evolution of precipitation in Maramureș County between 2006-2009, Preprints, Conference Air and Water components of the environment, University Press from Cluj, 388-393.

Pantelić, M., Dolinaj, D., Stankov, U., Leščešen I. 2013. Correlation Analysis of Impact of Natural Parameters on Water Quality of the River Danube Near Novi Sad for the Period 2004-2011, Geographica Pannonica 17-3, 74-78.

Rahimi, J., Ebrahimpou, M., Khalili, A. 2013. Spatial changes of extentded de Martonne climatic zones affected by climate change in Iran. Theoretical and Applied Climatology 112, 409-418. DOI 10.1007/ soo704-012-0741-8.

Reynard, N.S., Prudhomme, C., Crooks, S.M. 2001. The flood characteristics of large U.K. Rivers: potential effects of changing climate and land use. Climate Change 48-2, 343-359.

The "Romanian Waters" National Administration (RWNA), 2014. The maps of the flood hazard for all administrations basins and assessment of risks associated flood, as reported in WISE - European Programm of EC for all member states. On line: http://www.rowater.ro/Directiva\%2oInundaii/Directiva\%2oInunda\%C $8 \% 9$ Bii.aspx

Someș-Tisa Water Branch (S-TWB) 2013. Annual Synthesis of the Quality of water bodies in space Someș-Tisa river (in Romanian).

Stocker,T.F., Qin, D., Plattner, G.-K., Tignor, M., M.B., Allen, S.K., Boschung, J., Naules A., Xia., Y., Bex, V., Midgley, P. M. 2013. Climate Change 2013 - The Physical Science Basis Working Group I Contribution to the Fifth Assessment Report of the Intergovernmental Panel on Climate Change, Summary for Policymakers,Working Group I Technical Support Unit, $92 \mathrm{pp}$.

Internet 1: http://www.drought.unl.edu/MonitoringTools/ClimateDivisionSPI.aspx 